https://www.iol.co.za/sport/athletics/sa-medical-association-saysscience-used-by-iaaf-in-caster-semenya-case-is-flawed-19563844

10. Medical Council of India. Code of Medical Ethics, 2002. New Delhi: MCl; 2002, amended up to October 16, 2016 [cited 2019 Jun 2] Available from: https://old.mciindia.org/RulesandRegulations/ CodeofMedicalEthicsRegulations2002.aspx.

11. Medical Council of India. Competency based undergraduate curriculum for the Indian medical graduate. Vol 1. New Delhi: MCl; 2018 [cited on 29 Jan 2019]. Available from: https://www.mciindia.org/CMS/wp-content/ uploads/2019/01/UG-Curriculum-Vol-II.pdf

12. World Health Organization. What is health promotion? Geneva: WHO; 2016 [cited 2019 Jan 29]. Available from: https://www.who.int/features/ qa/health-promotion/en/.

13. IAAF regulations governing eligibility of athletes who have undergone sex reassignment to compete in women's competition. Place unknown: IAAF; 2011 June [cited 2019 Jun 2]. Available from:file:///C:/Users/foren/ Downloads/IAAF\%20Regulations\%20Governing\%20Eligibility\%20 of\%20Athletes.pdf

14. International Olympic Committee. IOC consensus meeting on sex reassignment and hyperandrogenism. 2015 Nov 15[cited 2019 Jan 29]. Available from: https://stillmed.olympic.org/Documents/Commissions PDFfiles/Medical_commission/2015-11_ioc_consensus_meeting_on sex_reassignment_and_hyperandrogenism-en.pdf.

15. IAAF hits back at World Medical Association as Caster Semenya row continues. Irish Examiner. 2019 May 8 [cited 2019 Jan 29]. Available from: https://www.irishexaminer.com/breakingnews/sport/iaaf-hits-back-atworld-medical-association-as-caster-semenya-row-continues-922797. htm

16. Ingle S. Caster Semenya able to run medication free for now as Swiss Court floors IAAF. The Guardian. 2019 Jun 3[cited 2019 Jan 29]. Available from: https://www.theguardian.com/sport/2019/jun/03/caster semenya-800m-swiss-supreme-court-ruling-iaaf.

17. GlobalSport Matters. Swiss court reverses earlier ruling, Semenya not allowed to run. Globalsportmatters.com. 2019 Jul 30[cited 2020 Mar 13]. Available from: https://globalsportmatters.com/science/2019/07/30/ swiss-court-reverses-earlier-ruling-semenya-not-allowed-to-run/

18. Singapore Criminal Law (Temporary Provisions) Act, Section 27A [cited 2019 Jan 29]. Available from: https://sso.agc.gov.sg/Act/ CLTPA1955?Provlds=P1IV-.

19. Jagadeesh N. Sex verification tests, ethical, legal and social aspects. Indian J Med Ethics. 2013 Jan-Mar;10(1). DOI: 10.20529/IJME.2013.011. Available from: https:/ijme.in/articles/sex-verification-tests-ethicallegal-and-social-aspects/

20. Bermon SF, Garnier PY, Hirschberg AL, Robinson N, Giraud S, Nicoli R, et al. Serum androgen levels in elite female athletes. J Clin Endocrin Metab. 2014 Nov 14; 99(11):4328-35. DOI:10.1210/jc.2014-1391.

21. Handelsman $H$, Hirschberg AL, Bermon SF. Circulating testosterone as the hormonal basis of sex differences in athletic performance. Endocrine Reviews. 2018 Oct; 39(5): 803-829. DOI: 10.1210/er.2018-00020.

22. Auchus RJ. Endocrinology and women's sports: the diagnosis matters. 80 Law and Contemp Probs. 2017[cited 2019 Jan 29]; 127-138. Available from: https://scholarship.law.duke.edu/lcp/vol80/iss4/6/

23. Allen DB. Hormonal eligibility criteria for 'includes females' competition: a practical but problematic solution. Horm Res Paediatr. 2016; 85(4): 278-82. DOI: 10.1159/000444054.

24. Bermon SF, Vilain E, Fénichel P, Ritzén M.Women with hyperandrogenism in elite sports: scientific and ethical rationales for regulating. J Clin Endocrinol Metab. 2015 Mar; 100(3): 828-30. DOI:jc.2014-3603

25. Ritzén $M$, Ljungqvist $A$, Budgett $R$, Garnier PY, Bermon $S$, LindénHirschberg $A$ et al. The regulations about eligibility for women with hyperandrogenism to compete in women's category are well founded. A rebuttal to the conclusions by Healy et al. Clin Endocrinol. 2015 Feb; 82(2): 307-8

26. Gooren, L. The significance of testosterone for fair participation of the female sex in competitive sports. Asian J Androl. 2011 Sep; 13(5): 653-4. DOI: 10.1038/aja.2011.91.

27. Huang G, Basaria S. Do anabolic-androgenic steroids have performanceenhancing effects in female athletes? Mol Cell Endocrinol. 2018 Mar 15; 464:56-64.DOI: 10.1016/j.mce.2017.07.010

28. World Athletics. IAAF publishes briefing notes and Q\&A on female eligibility regulations. IAAF website. 2019 May 7 [cited 2019 Jan 29]. Available from: https://www.iaaf.org/news/press-release/questionsanswers-iaaf-female-eligibility-reg

29. Sanchez FJ, Martinez-Patino MJ, Vilain E. The new policy on hyperandrogenism in elite female athletes is not about "sex testing". J Sex Res. 2013 Feb; 50(2): 112-5.

30. World Health Organization. Integrating gender perspectives in the work of WHO. Geneva:WHO, 2002 [cited 2019 Jan 29]. Available from: https:// www.who.int/gender/mainstreaming/ENGwhole.pdf

31. Peters SAE, Norton R. Sex and gender reporting in global health: new editorial policies. BMJ Glob Health. 2018 Jul 26; 3(4):e001038. DOI: 10.1136/bmjgh-2018-001038.

32. Trbovc JM, Hofman A. Toolkit for integrating gender-sensitive approach into research and teaching. Gendering the Academy and Research: Combating Career Instability and Asymmetries [cited 2019 Jan 29]. Available from: https://eige.europa.eu/sites/default/files/garcia toolkit_gender_research_teaching.pdf

\title{
The ethics of penal amputation
}

\section{ANJAN K DAS}

\section{Abstract}

Malaysia is a South East Asian country with a racially diverse population. Islam is the state religion and about $60 \%$ of the population is Muslim, but the rights of other religious groups are

Author: Anjan K Das (AnjanKumar.Das@taylor's.edu.my), Associate Professor, Taylor's University School of Medicine, Faculty of Health and Medical Sciences, Taylor's University, 1, Jalan Taylor's, 47500, Subang Jaya, Selangor, MALAYSIA.

To cite: Das AK. The ethics of penal amputation. Indian J Med Ethics. $2020 \mathrm{Apr}-$ Jun;5(2) NS: 143-8. DOI: 10.20529/JME.2020.032.

Published online on April 1,2020.

Peer Reviewers:

( ) Indian Journal of Medical Ethics 2020 protected by law. The Parti Islam se Malaysia, which has ruled the state of Kelantan since 1999, and believes that Malaysia should be ruled by Sharia law, recently proposed the implementation of Hudud laws in Kelantan. However, the federal government has ruled out its implementation. The suggestion stirred up a controversy among the physician community and the Malaysian Medical Association rejected a proposal by the state's political leadership to utilise the services of qualified surgeons to carry out punitive limb amputations. Several Islamic states such as Sudan, Saudi Arabia, and Iran practice Islamic penal justice, including amputations. The question therefore arises: how should a modern medical practitioner approach this ethical question? This study focuses mainly on Malaysia, but draws upon practices in other Islamic countries also. 


\section{Introduction}

Malaysia is a South East Asian country with a mixed population and rich racial diversity. Islam is the state religion, and about $60 \%$ of Malaysia's population is Muslim, although the rights of other religious and ethnic groups are protected by law. It is sometimes held up as a poster boy of a moderate Islamic nation and deserves this reputation as it has, largely, protected its minorities (1). While the majority of the population is composed of Malays (who are Muslims), $40 \%$ of the population comprises Chinese and Indian communities. The Chinese community is economically dominant, while the Indian community is comparatively much poorer. The people are mostly Buddhists, Hindus, or followers of Confucius. Malaysia is proud of its status as a modern Muslim country where, while the dominance of Islam is non-negotiable, it has made great strides in inclusivity on the road to development.

The Malaysian state of Kelantan has been ruled by an Islamic party, the Parti Islam se Malaysia (PAS), since 1999. This party, which believes that Malaysia should be ruled by Sharia law, recently proposed the implementation of Hudud laws in the state. The present constitutional arrangements do not allow such implementation in a single state, and the federal government has ruled it out. However, the suggestion stirred up a controversy among the physician community in Malaysia. The Malaysian Medical Association rejected a proposal by the deputy chief minister of the state to utilise the services of qualified surgeons to carry out punitive limb amputations. On the other hand, I-Medik, a Muslim medical group, blamed the Malaysian Medical Association for being hasty in its reaction and not understanding the Islamic penal code (2).

The $14^{\text {th }}$ general elections in Malaysia in 2018 saw the PAS retaining power in the state of Kelantan while also capturing power in Terengganu, a state where they have been in and out of power over the past two decades. This has led to a lot of speculation that there will be fresh attempts to implement Hudud laws in states ruled by the party. In fact, the deputy chief minister of Kelantan has stated that RM 1 million (about USD 330,552) will be allocated to researching how the policy may be implemented (3).

There has been a recent resurgence in conservative Islamic practices in the country, in response to the feeling that Muslims are being victimised all over the world. This has led many Muslims to shift to a more traditional form of Islam based on hardline Wahhabi customs mainly imported from Saudi Arabia (4). It is in this context that the new push for Hudud punishments should be viewed.

Several Islamic states such as Sudan, Saudi Arabia, and Iran practise Islamic penal justice, including amputations. This study will mainly focus on Malaysia while drawing upon practices in other Islamic countries. The question remains of how a modern medical practitioner should approach this ethical issue. A hypothetical situation may be as follows:

$\operatorname{Dr} A$, a specialist surgeon, is assigned by the head of the department of surgery to perform an amputation of the right hand at the wrist for a prisoner who has been convicted for theft and has been sentenced to amputation by Islamic law. Should he comply with the request? What are the ethical aspects that would govern this assignment?

\section{Analogous situations}

It is entirely possible that for an audience raised in modern Western (and specifically Christian) traditions, this may be considered remote from their interests or needs. This is also true for most Indian surgeons practising in India and one can be fairly sure that the above dilemma is unlikely to be faced by any Western or Indian surgeon in the foreseeable future. However, there are circumstances in which a surgeon may face a similar type of dilemma even in western-style democracies. In the fairly recent past, a Scottish surgeon, Robert Smith, was requested by a patient to amputate his healthy leg (5). This is a known psychiatric condition, first described in 1977, which involves two related but distinct conditions; acrotomophilia, an attraction towards amputees, and apotemophilia, a sexual attraction to becoming an amputee. People with this condition are not rare; Johnston and Elliot (2002) reported that a Yahoo chat group for people who wanted to have their limbs amputated had 2,100 members (6). After consulting with psychiatrists, Smith decided to go ahead with the surgery, which he completed to the full satisfaction of the patient. He then repeated the surgery on another similar patient. However, while planning a third operation, he was stopped by the trust that ran his hospital.

Another issue that has similar ramifications is the practice of execution by lethal injection. In the United States, 29 states still permit the death penalty, and all of them utilise lethal injections as the method of execution (7). Now, while other commonly used methods of execution do not require the active participation of the physician (they are only required to certify the death), in the case of lethal injections, the participation of a physician is sometimes essential. In fact, in 27 US states, doctors must compulsorily be present at the execution. In the landmark case of California Department of Corrections $v$ Morales [514 US, 499 (1995)] in 2006, a federal district judge had ruled that in order to conduct an execution by lethal injection, the state must have a qualified medical person certify that the individual is unconscious before the administration of potassium chloride, which stops the heart (8).This meant that physicians needed to participate in the execution process, and this threw up a host of ethical issues akin to those in penal amputation. An examination of the ethics of penal execution can inform the discussion on the dilemmas faced in penal amputation.

\section{Hudud laws and their implementation}

It may be useful at this juncture to examine the exact provisions of Hudud law. Surprisingly, most proponents as well as opponents of the law appear to be unclear about what the law states and how it is to be implemented $(9,10)$. It is necessary to point out here that the laws described in the following section are based on the majority Sunni view. I have not discussed other interpretations as the Sunni school of Islam is the official religion of Malaysia (11). 
In the words of Souryal and Potts, "Islamic law has two primary sources: the Shariah, which is a theocratic legal system based on a divine code revealed to the Prophet Mohammad (PBUH) and the Sunnah, or the acts of the prophet" (9). The concept of Hudud, however, is not found in the Quran, though it has been mentioned in the Hadiths, believed by Muslims to be an authentic record of the ideas of Prophet Mohammad (PBUH). The word Hudud is plural for the Arabic word "hadd", meaning "the final limit". The Quran has several passages that mention the "limits of God", beyond which Muslims are warned never to transgress. The specific Hudud crimes were compiled by early Muslim lawmakers from references made by the Prophet (PBUH) and early Muslims. It is accepted that Hudud crimes are violations against God and the punishments for them are laid down in the Quran or the Sunnah. The crimes that fall under this category are zina (fornication), sariga (some types of theft), qadif (false accusation of fornication), shurb-al khamur (drinking alcohol), and hiraba (armed robbery). There are other crimes that are considered by some (but not all) schools of law to be Hudud crimes as well. These include sodomy, apostasy, and assassination for the purpose of robbery. The important point to note here is that Hudud crimes are considered crimes against God himself. Thus, their penalties are considered absolute, nonnegotiable, and unpardonable. As such, a proven Hudud offence carries, as it were, a mandatory sentence laid down by the Quran, which cannot be mitigated by mortal judges. These include hand amputation for theft, 100 lashes for fornication, 40 lashes for alcohol consumption, and so on (9).

One important issue that is often overlooked when considering Hudud crimes and their punishment is that the burden of proof is set extremely high. For such crimes, there are only two types of evidence that can be accepted. The first is iqrar (confession). The confession, however, can be retracted at any time, even up to the moment of punishment. The second type of proof is eyewitness testimony. The number of eyewitnesses required varies depending upon the crime. Four male eyewitnesses are required to prove guilt in cases of adultery and two for theft. The testimony of two female witnesses equals that of a man, and female witnesses are permitted only if there is also a male witness. In addition, the witness must be: (i) a person of moral integrity; (ii) above the age of puberty; (iii) sane at the time of observing the offence and when giving testimony; and (iv) free of criminal convictions and should not have engaged in any deviant behaviour (9).

The purpose of setting such high standards of evidence was obviously to prevent the law from being applied routinely. This was acknowledged by the Prophet (PBUH) himself, who, it has been reported, tried to stop a person accused of adultery from confessing. In fact, in Islamic societies, Hudud punishments are rare events "because Muslim jurists made the evidentiary requirements and the technical pre-conditions for the enforcement of the hudd practically impossible to fulfill or because they admitted so many mitigating factors to the point that only a criminal who was most determined to be punished could be made to suffer the hudud penalties" (10). The criminals could, however, be punished by tazir or discretionary punishments. This is analogous to American civil law, in which the burden of proof is less than it is in criminal law, and the punishment is less severe as well (12). Scholars have suggested that the presence of such laws has led to low levels of crime in Islamic societies. They have also stated that after a Hudud punishment, the criminal could be rehabilitated in society instead of being imprisoned, given that prisons are notorious for reinforcing criminal proclivities rather than acting as institutions of correction (13).

One question that arises here is whether confessions are obtained under coercion. Under Islamic law, this is not permissible. Having said that, it is well known that several Islamic regimes do not follow such niceties, and confessions are forced out of prisoners by torture. This study does not address this, as it is impossible to discuss ethics in such societies. Our discussion will be confined to societies where the rule of law prevails, even if they may not be "liberal" societies in the dictionary meaning of the term. The argument has been further clarified in the next section.

The method of amputation was fairly standardised in medieval times. It was usually carried out in the central square of the town on Fridays after the noon prayer. The condemned person was produced, the verdict was read out aloud, and the person's arm was stretched out over a flat surface. In a quick move, the professional executioner exerted strong pressure, pulling the hand away from the wrist and severing the limb at the wrist. A male doctor and nurse were required to be present, who would then take over to stop the bleeding and bandage the wrist (9).

If the role of the physician was limited to administering care to the criminal after the punishment had been carried out, there would not be much of an ethical dilemma, but in many countries where Hudud law has been implemented or is being implemented, physicians are expected to perform the amputation. This is true of Saudi Arabia, Iran, and Pakistan, and of the proposed Hudud laws of Kelantan, Malaysia. In Libya, the amputation may be performed in a hospital with recourse to anaesthesia. In Iran, a special device was developed by the faculties of medicine of two major universities to facilitate the amputation of fingers (14). Sudanese law also specifies that the punishment must be carried out by a medical practitioner (15).

\section{Ethical arguments}

We will now proceed to summarise the arguments for and against the procedure.

John Rawls, the American philosopher, provides a description of a "decent" society (16). Such a society must mainly conform to four main conditions: (i) respect for other societies; (ii) adherence to basic human rights (principal among which are the right to life, right to liberty, right to personal property, and the right to formal equality); (iii) a legal system that incorporates the idea of the common good; and (iv) a reasonable consultation hierarchy, which may or may not incorporate free and fair elections, but attempts to reflect the interests of all groups. 
This decent society is not a modern liberal society that places individual rights on a pedestal. Rawls' view is that such a nonliberal nation may still be peace-loving, non-belligerent, and have an institutional framework that allows representation (though it may not be a full democracy). In addition, such a society may tolerate minority and human rights. However, the physician may need to participate in corporal punishment or even torture if it is considered to be in the "national interest".

Malaysia may be considered a "decent" society by this definition. Malaysia has a written constitution, a welldeveloped legal system including a well-defined route of appeal, and by all accounts, the courts have been liberal in their interpretation of the law, particularly when they encroach on the rights of minorities. The government represents the people, and elections are regularly held. While it has been argued that press freedom is compromised, and that the election mechanism is rigged in favour of the incumbent government, the last election (held in 2018) saw the fall of the party that had ruled uninterruptedly since independence.

In such a decent society, Islamic law may be enforced, including amputation. While liberal societies would consider this an abhorrent practice, it may be argued that such punishments preserve society and thereby help attain a higher goal. These practices are usually justified using the following arguments: first, it is an act of penance that helps rehabilitate the criminal; second, is an opportunity for the society to demonstrate its benevolence through this rehabilitation; and third, it acts as a deterrent to such crimes. It has been argued that this is an example of a link between the law and the community and has the salutary effect of swift punishment, rehabilitation, and crime prevention (12).

The argument of course smacks of paternalism. The society decides, on the basis of religious teachings, what the fitting punishment is and its implementation with no regard to individual rights. Further, in doing so, the doctor is duty bound to abandon his "do no harm" principle.

It would be useful to clarify our ideas about the ethics of the punishment itself. If the punishment is unethical, then the whole argument is infructuous. If a society can agree that penal amputation offends its ethics, then no one should be participating in the trial and sentencing, leave alone physicians. However, the punishment is considered ordained by the Almighty and thus it is not within the purview of mere mortals to modify it. In most Islamic societies, this debate is hushed up, and by tacit consensus, Hudud punishments are not implemented. However, they are implemented in some countries, and it is here that the dilemma truly rises. In these societies, the ethics of Hudud cannot be questioned as these laws are thought to be divinely inspired. There is no room for modern ethical arguments. But what about those of us looking in from the outside? What is the ethical basis of this punishment? Here, the ethics of capital punishment may offer guidance of a sort. State-sponsored capital punishment has been defended and condemned by "reasonable people in good faith."(17) Thus, there appears to be no reason why reasonable people should not be able to live with the concept of Hudud punishment. This analogy has been used not to analyse the ethical arguments for or against the participation of doctors in capital punishment. It is necessary to highlight that in many cases, governments have not found it difficult to recruit physicians to participate. As Alper's paper (8) demonstrates, while there are non-binding ethical objections to participation in the US, it is not difficult to find physicians who are willing to flout these guidelines. They are also not subjected to penalties. Thus, it is possible for surgeons to be convinced by personal arguments which may allow them to participate in penal amputations. In this paper, I would like to examine whether this is ethical at least from my point of view as a practising surgeon.

Now, the question remains: are doctors justified in participating in penal amputation? What are the arguments for and against participating? The first, and most important, argument against participation is the Hippocratic Oath to first do no harm. Amputating a healthy limb goes against the basic tenets of medical practice. However, as a counter to this, there is the argument that in certain circumstances, it is considered ethical in some societies to even euthanise a patient. While there are many checks and balances to the process, it cannot be denied that in the final instance, the patient does undergo harm at the hands of the physician (18). Why then should amputation be considered unethical when it is a judicial requirement? Here, of course, the usual riposte is that euthanasia is only considered if and when there is a clear consent from a competent patient. However, it can be argued that the prisoner who is to undergo amputation has also consented to it by confessing to a Hudud crime. Even if they have not, it is difficult to argue that a just punishment requires the prisoner's consent for the sentence to be carried out. In any case, there are at least three instances where healthy organ removal is morally justified: live organ donations, cosmetic surgery when, say, a healthy nose is operated on, or in sex reassignment operations when genitalia may be excised (19). Organ donation, in particular, is important in this context. Organ donations subject the donor to a major surgical procedure which can be complicated and even life-threatening. The procedure is often not entirely voluntary, as familial pressures and financial need may play a role. But surgeons do perform such procedures, and ethical arguments have been developed in favour of this procedure. It is also true that if there is a constitutional provision for Hudud punishment, there has to also be a method of carrying it out, and surgical amputation is perhaps the best option.

One hypothetical question may be raised. What if the prisoner consents to limb amputation? Would that remove any ethical objections? Another, perhaps more relevant, argument suggests that participating in such punishments could set the concerned surgeon on a slippery slope that leads to other unethical practices such as torture. This argument has been vehemently refuted, as participation in state executions has not led to any such incidents, nor has the public lost faith in doctors as feared. This not to say that doctors are above criticism. Following the Tuskegee incident in the USA, where it 
was revealed that unethical trials were being conducted on the African American community, physicians were regarded with mistrust, at least within minority communities, long after the incident was exposed and action taken (20).

Baum, arguing in favour of physician participation in executions, has stated that patients facing execution are akin to terminally ill patients (21). Doctors have an ethical obligation to reduce the suffering of, say, a dying cancer patient. A corollary, therefore, is that the dying condemned prisoner also deserves the best "treatment" that the doctor can give. In the case of penal amputation, this implies that the prisoner deserves a surgeon's specialised services rather than facing an amputation by untrained persons. Black and Levine, however suggest that this argument does not hold good (22). Surgeons would be able to ensure a less painful and cleaner amputation, but that is not the purpose of their training. Just because physicians have the skill to do so, it is not ethical to use them for this purpose.

An ingenious argument, which was again originally developed in relation to executions, suggests that as the amputation of a normal organ does not count as a medical procedure, the laws of medical ethics do not apply to these patients (17). Thus, the surgeon who does this procedure is not bound by relevant ethical norms. This argument is weak as the procedure requires a well-defined medical protocol and medical equipment and it is surely farfetched to claim that this is not a medical procedure.

Here, it may be useful to bring in another dimension-that is, the doctor's duties to society. Physicians routinely carry out activities that have nothing to do with their patients welfare, but serve society at large. For instance, reporting infectious diseases may, in fact, harm the patient's interests as they may need to be quarantined or forced to be admitted to a specialised facility. However, this does not raise any ethical quandaries, nor does the physician wrestle with their conscience afterwards. Then, can penal amputation also be considered a societal contribution? It may be considered analogous to the non-use of expensive medication for a patient who cannot afford it. Similarly, it can be considered equivalent to the use of placebo controls when conducting a medical trial. The patient undergoes medical procedures (blood tests, examinations, imaging) but does not reap any benefits; instead, they expose themselves to the prospect of harm (adverse events) in order to further medical research, or in other words, to further societal good. While participating in the placebo group of a study, especially in a randomised controlled surgery study which may involve sham operations, the significant possibility of harm is always present (23). While this was a hotly debated issue in the past, most ethicists at the present time are of the opinion that there are no major ethical objections.

A final argument that has been proposed is that not participating in penal amputation procedures harms the interests of the victims of the crimes. They may suffer from medical illnesses, including psychiatric problems, because of the crime itself and its consequences (24). This is an extension of the society benefit argument, but it has moral force. However, this argument depends on the idea that such punishments have a deterrent effect which may not really be the case.

\section{What conclusion can be drawn from the above arguments?}

It appears that it is incorrect to condemn all practitioners who participate in penal amputations out of hand. There are cogent reasons why a surgeon who lives in a society that permits such punishments may participate. These cannot be discounted. If liberal societies can live with the participation of physicians in executions, then it is not quite clear why penal amputations should be ethically unacceptable. While most professional bodies in the United States consider participation in penal amputation unacceptable, no regulatory body has ever condemned a physician participating in executions. While the UN Principles of Medical Ethics (25) are clear that a physician cannot participate in any cruel, inhuman, and degrading punishment, the arguments for not considering specific Hudud punishments cruel or inhuman exist and thus may protect a physician from ethical sanction. However, the so-called "decent" society (26) which enforces such punishment must ensure that the physician is not coerced into carrying out this operation. If the physician is forced to do so under the threat of punitive measures, it is a difficult situation devoid of ethical norms.

This has particular relevance to Malaysia, where while the bulk of the population is Muslim, and may, in principle, accept Hudud punishments in the future (though there is no consensus for their implementation at present), there is a significant minority of physicians, specifically surgeons, who may be impacted by the requirement to carry out penal amputations. Malaysia is a "decent" society and will no doubt continue to be so in the foreseeable future; thus, the ethical arguments developed above will possibly be of value in deciding the course of action in case Hudud laws are implemented.

However, it is also clear that a liberal society may balk at the argument used to justify penal amputations. This is also an acceptable point of view, as the entire issue hinges on whether the punishment is seen as acceptable to liberal society. A society that does not accept judicial executions may decide that penal amputations are unethical and may decide to proscribe any physician who has participated in such punishments. They would certainly be well within their rights to do so.

Thus, while it may be ethically permissible to carry out these surgical procedures in a "decent" society, the surgeon must not be under any obligation to do so. However, in Western style liberal societies, it may be considered abhorrent and the physician who agrees to carry out such an operation would be considered ethically beyond the pale and may expect peer group and judicial sanctions. 


\section{Acknowledgements}

This study was funded by the Bochum International Visiting Fellowship in Medical Ethics Programme at the Institute of Medical Ethics and History of Medicine, Ruhr University, Bochum, Germany.

I gratefully acknowledge the help of Alexa Nossek, Department of Ethics and History of Medicine, Ruhr University, Bochum, Germany, for her help in clarifying these arguments during repeated conversations.

\section{References}

1. Thio L-A. Constitutional accommodation of the rights of ethnic and religious minorities in plural democracies: Lessons and cautionary tales from South-East Asia. Pace Int Law Rev. 2010 Jan [cited 2020 Mar 20];22(1):43. Available from: http://digitalcommons.pace.edu/pilr/ vol22/iss $1 / 2$

2. About Islam. Hudud amputations divide Malaysia doctors. 2016 Jan 6 [cited 2019 June 18]. Available from: http://aboutislam.net/muslimissues/hudud-amputations-divide-malaysia-doctors/:

3. Saat N. Will PAS governments in Kelantan and Terengganu push for Islamic laws? Perspective. 2018 June 25[cited 2019 Dec 27]; 2018(33): 1-7 Available from: https://www.iseas.edu.sg/images/pdf/ISEAS_ Perspective_2018_33@50.pdf.

4. Osman MNM. The Islamic conservative turn in Malaysia: impact and future trajectories. Contemporary Islam. 2017 April;11(1): 1-22. DOI: 10.1007/s11562-016-0373-3.

5. Dyer C. Surgeon amputated healthy legs. BMJ. 2000 Feb 5; 320(7231): 332.

6. Johnston J, Elliott C. Healthy limb amputation: ethical and legal aspects. Clin Med JRCPL.2002 Sept [cited on 2019 Dec 27]; 2(5):431-5. Available from: https://www.researchgate.net/publication/11019905_Healthy_ limb_amputation_ethical_and_legal_aspects.

7. Death Penalty Information Center. States with and without the death penalty - 2020[cited 2020 Mar 13]. Available from: https:// deathpenaltyinfo.org/state-and-federal-info/state-by-state

8. Alper $\mathrm{T}$. The truth about physician participation in lethal injection executions. NCL Rev. 2009; 88:11 [cited on 2010 Feb 15]. Available from: https://papers.ssrn.com/sol3/papers.cfm?abstract_id=1424270.

9. Souryal SS, Potts DW, Alobied AA. The penalty of hand amputation for theft in Islamic justice. J Crim Justice. 1994;22(3):249-65.DOI: https:// doi.org/10.1016/0047-2352(94)90021-3

10. Fadl KAL. Quranic ethics and Islamic law. Journal of Islamic Ethics. 2017 Aug 14[cited 2020 Feb 15];1(1-2): 7-28 Available from: https://www. searchforbeauty.org/2017/08/14/qur-anic-ethics-and-islamic-law-injournal-of-islamic-ethics-1-brill-2017/

11. Hassan MHB. Explaining Islam's special position and the politic of Islam in Malaysia. Muslim World. 2007 Apr [cited on 2019 Dec 27]; 97: 287-
316. Available from: http://haniff.sg/wp-content/uploads/2012/12/ explaining-islams-special-position-and-politics-of-islam-in-malaysiamuslim-world.pdf.

12. Ali B. Islamic law and crime: the case of Saudi Arabia. Int J Comp Appl Crim Justice.1985; 9(1-2): 45-57. DOI: https://doi.org/10.1080/0192403 6.1985 .9688820 .

13. Brown J. Stoning and hand cutting: understanding the Hudud and the Shariah in Islam. Texas: Yaqeen Institute for Islamic Research;2017 Jan 12. Available from: https://yaqeeninstitute.org/jonathan-brown/ stoning-and-hand-cutting-understanding-the-hudud-and-theshariah-in-islam/.

14. Atighetchi D. Some aspects of medical ethics. In: Atighetchi D. Islamic Bioethics: Problems and Perspectives. Dordrecht: Springer Netherlands; 2007. 378 pgs.

15. Gravelle KB. Islamic Law in Sudan. ILSA J Int'I \& Comp L. 1998; 5(1):1-22.

16. Rawls J. The Law of Peoples. Cambridge: Harvard University Press; 1999.

17. Litton P. Physician participation in executions, the morality of capital punishment, and the practical implications of their relationship. J Law Med Ethics. 2013 April 1;41(1):333-52.

18. Widdershoven GA. Beyond autonomy and beneficence: The moral basis of euthanasia in the Netherlands. Ethical Perspect. 2002[cited on 2020 Feb 15]; 9(2-3):96-102. Available from: http://www.ethicalperspectives.be/viewpic.php?LAN=E\&TABLE=EP\&ID=52.

19. Johnston J, Elliott C. Healthy limb amputation: ethical and legal aspects.Clin Med (London). 2002 Sept-Oct;2(5):431-35.DOI:https://doi. org/10.7861/clinmedicine.2-5-431.

20. Burgess JA. The great slippery-slope argument. J Med Ethics. 1993 Sept;19(3): 169-74.DOI: http://dx.doi.org/10.1136/jme.19.3.169.

21. Baum K. "To Comfort Always": Physician Participation in Executions. N.Y.U.J. Legis. \& Pub. Pol'y. 2001; 5(47), 61-7.

22. Black LJ, Levine MA. Ethical prohibition against physician participation in capital punishment. Mayo Clin Proc. 2008 Jan; 83(1): 113-4. DOI: https://doi.org/10.4065/83.1.113.

23. Das AK: Randomised clinical trials in surgery: a look at the ethical and practical issues. Indian J Surg. 2011 Aug; 73(4): 245-50. DOI: https://doi. org/10.1007/s12262-011-0307-5.

24. Keane, M. The ethical "elephant" in the death penalty room. Am J Bioethics. 2008 Nov; 8(10): 45-50. DOI: https://doi. org/10.1080/15265160802393025.

25. UN General Assembly Resolution No 37/194 of December 18, 1982. Principles of Medical Ethics relevant to the Role of Health Personnel, particularly Physicians, in the Protection of Prisoners and Detainees against Torture and Other Cruel, Inhuman or Degrading Treatment or Punishment. Geneva: UNOHCHR; 1982 Dec18[cited 2020 Mar 22], updated Dec 1996. Available from: https://www.ohchr.org/EN/ Professionallnterest/Pages/MedicalEthics.aspx

26. Rawls J. The law of peoples with "the idea of public reason revisited". Cambridge, Mass: Harvard University Press; 1999.

\section{Be a part of IJME}

IJME invites readers to submit research studies, comments, case studies, reports, reviews, letters, as also poems, short stories, original paintings and photographs of print quality ( both in colour and B/W) to be considered for publication.

All submitted matter is subject to peer review.

Contributors are neither paid nor charged any fee for published matter. 